\title{
Landslides
}

June 2018, Volume 15 Issue 6 Pages 1085-1095

http://dx.doi.org/10.1007/s10346-018-0956-6

http://archimer.ifremer.fr/doc/00425/53636/

(c) Springer-Verlag GmbH Germany, part of Springer Nature 2018

\section{Morphological control of slope instability in contourites: a geotechnical approach}

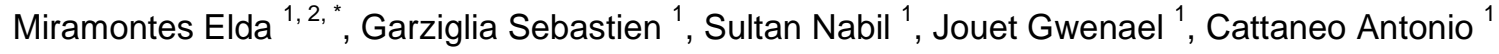 \\ ${ }^{1}$ IFREMER, Géosciences MarinesPlouzané, France \\ ${ }^{2}$ CNRS, UMR6538, Domaines Océaniques, IUEM-UBOPlouzané, France \\ *Corresponding author : Elda Miramontes, email address : Elda.Miramontesgarcia@univ-brest.fr
}

\begin{abstract}
:
Contourite drifts are sediment bodies formed by the action of bottom currents. They are common features found on continental slopes and are often affected by slope failure. However, processes controlling slope instability in contourite depositional systems are still not well constrained, and it is not clear whether contourites have particular properties that make them more susceptible to slope failure. In this study, we compare sedimentological and geotechnical properties of contouritic and hemipelagic sediments within the Corsica Trough (northern Tyrrhenian Sea) using geophysical data sets and sediment cores in order to get a better understanding of the controlling factors of slope stability. Geomorphological and slope stability analyses reveal that differences in sediment properties have little influence on the location of submarine landslides, in comparison with the morphology of the drifts. Hence, the steep downslope flanks of plastered drift deposits are the most susceptible zones for local failure initiation. Moreover, as erosion is common at the foot of plastered drifts, undercutting is thought to contribute to the development of large-scale failure up to the point that submarine landslides are triggered.
\end{abstract}

Keywords: Sediment drift, Submarine landslide, Undrained shear strength, Hemipelagite, Mediterranean Sea 


\section{Introduction}

Contourite drifts are sediment deposits related to the interaction of bottom currents and seafloor morphology that are commonly formed along continental margins (Stow and Faugères 2008) and are often affected by slope failure (Laberg and Camerlenghi 2008). Submarine landslides initiated in contourites have been identified worldwide in many different oceanic settings: in siliciclastic systems in high latitudes (Laberg et al. 2001; Laberg et al. 2002; Wilson et al. 2004; Bryn et al. 2005a,b; Vanneste et al. 2006) and in mid-latitudes (Verdicchio and Trincardi 2008; Krastel et al. 2011; Lüdmann et al. 2012; Preu et al. 2013; Ercilla et al. 2016; Hernández-Molina et al. 2016; Hübscher et al. 2016), as well as in carbonate systems in low latitudes (Principaud et al. 2015; Tournadour et al. 2015).

Although mass-wasting processes are common in contourite systems, it has never been shown whether differences in their sediment properties compared to hemipelagites could result in a preferential formation of slope failures within contourites. Large and well-studied submarine landslides, such as the Storegga Slide offshore Norway, are located within contourites (Laberg et al. 2002; Bryn et al. 2005a; Baeten et al. 2014; Laberg et al. 2016). However, they are located in high latitudes where the differences in sediment properties of fine-grained contourites versus glaciogenic sediments are more distinct. In midlle to low latitude contourite systems such as in the Corsica Trough, where the slope is dominated by hemipelagic and contouritic deposits, this strong lithological contrast is absent. Actually, muddy contourites and hemipelagites are difficult to differentiate only based on standard sedimentological analysis, since both types of sediment tend to be homogeneous, poorly bedded, badly sorted and highly bioturbated (Stow and Tabrez 1998; Stow and Faugères 2008). In order to distinguish them we use seismic reflection and multibeam bathymetric data, in which contourites are often characterised by a mounded shape (HernándezMolina et al. 2008). In this study, we consider as a contourite, sediment bodies that clearly show a mounded shape induced by bottom currents. Seafloor with a smooth topography and no mounded shape is classified as hemipelagic.

The aim of this study is to compare the geotechnical characteristics of contourite drifts with noncontouritic deposits within the Corsica Trough (Northern Tyrrhenian Sea, Fig. 1) in order to investigate whether contourites have intrinsic or inherited properties that make them susceptible to slope failure. The Corsica Trough is an ideal study area because hemipelagites and contourites are located in close proximity but are spatially separated. In addition, the available data set is of high quality, including boreholes and long undisturbed Calypso piston cores (Fig. 1). 


\section{Regional setting}

The Corsica Trough is a confined basin located in the Northern Tyrrhenian Sea, between Corsica and the Tuscan Shelf (Fig. 1). It is an asymmetric basin in terms of dominant sediment processes. The eastern flank is formed by the Pianosa Ridge and has relative steep slopes, ranging in between $3^{\circ}$ and $10^{\circ}$, reaching up to $20^{\circ}$ locally (Fig. 1b; Miramontes et al. 2016a). The Plio-Quaternary sedimentation along this flank is dominated by contouritic deposits (Marani et al. 1993; Roveri 2002; Cattaneo et al. 2014; Miramontes et al. 2016b) and mass-wasting processes that resulted in the formation of 11 mass transport deposits, identified at the foot of the slope (Figs. 1a and 2; Miramontes et al. 2016a). South of Pianosa Island, the continental slope is formed by a convex-shaped plastered drift. It is separated from a mounded drift by an incision (moat) located at the lower slope (Fig. 1; Miramontes et al. 2016b). A moat is a zone where faster bottom currents prevent sediment deposition and may also induce erosion. Offshore from Elba Island, south of the Elba Canyon, multicrested drifts are present on the continental slope. The crests of the drifts are parallel to each other and separated by moats. These drifts are oblique to the continental slope (Fig. 1; Miramontes et al. 2016b).

The western flank of the Corsica Trough has a gentle slope (mean values between $2^{\circ}$ and $3^{\circ}$ ) and its sediment is mainly composed of hemipelagites and turbidites (Figs. 1 and 2; Gervais et al. 2006; Deptuck et al. 2008; Calvès et al. 2013). The turbidite system was connected to the continental shelf through submarine canyons that are still evident on the seafloor (Fig. 1), and it was active during sea level low-stands (Calvès et al. 2013). Some contourite deposits (plastered drifts) are also present on the upper part of the Corsican continental slope (Figs. 1 and 2).

\section{Materials and methods}

\section{Bathymetric and core data}

The bathymetry used for this study is a compilation of GEBCO dataset (GEBCO_08, version 2010-0927, http://gebco.net) and multibeam bathymetry acquired during the CORFAN survey (Savoye 1998) in 1998 onboard the R/V L'Europe, the CORFAN 2 survey (Savoye 2001) in 1999 onboard the R/V Le Suroit, the SIGOLO survey (Savoye 2008) in 2008 onboard the R/V Le Suroît, and in 2013 the surveys PRISME2 (Cattaneo 2013a), PAMELA-PAPRICA (Cattaneo and Jouet 2013) onboard the R/V L'Atalante, and PRISME3 (Cattaneo 2013b) onboard the R/V Pourquoi pas?. The seismic data were collected during the SIGOLO survey in 2008 onboard the R/V Le Suroît (Savoye 2008) and the PRISME2 survey in 2013 onboard the R/V L'Atalante (Cattaneo 2013a).

In this study we used eight Calypso piston cores collected along the Pianosa Ridge during the PRISME3 cruise (Cattaneo 2013b) onboard the R/V Pourquoi pas? in 2013, and two borehole cores collected in the central and western flank of the Corsica Trough during the GOLODRILL cruise onboard the R/V 'Bavenit' in 2009 (Fig. 1a). 


\section{Sediment physical properties}

The physical properties of cored sediments, including gamma-density and P-wave velocity, were measured on whole core sections every $1 \mathrm{~cm}$ with a Geotek Multisensor Core Logger (MSCL). The Pwave velocity of borehole GDEC4-2 was measured with a laboratory celerimeter every $40 \mathrm{~cm}$ on split sections.

\section{Grain size}

Grain size analyses were performed using a Coulter LS200 laser microgranulometer on boreholes GDEC4-2 and GDEC8-2 (every $10 \mathrm{~cm}$ ) and on Calypso piston cores PSM3-CS009 and PSM3-CS011 (with a variable spacing, ranging from $10 \mathrm{~cm}$ in the homogeneous muddy facies to $2 \mathrm{~cm}$ in the sandy areas and mud-sand transitions). A Malvern Mastersizer 3000 laser microgranulometer was used to do grain size analyses on cores PSM3-CS017 (every $15 \mathrm{~cm}$ ) and PSM3-CS021 (every $10 \mathrm{~cm}$ ) in IFREMER laboratories. No chemical pre-treatment was performed on sediments, but we stirred the samples mechanically before the analyses to ensure particle dispersion. Comparative grain size analyses were also performed on selected muddy samples $(<63 \mu \mathrm{m})$ with a Sedigraph $5100(\phi 4$ to 13) in CNR-ISMAR laboratories and with the Coulter LS200 laser microgranulometer in IFREMER laboratories in order to better determine the fraction of sediment finer than $10 \mu \mathrm{m}$, since the laser microgranulometer cannot correctly measure the size of the clays due to their shape and because we did not apply any chemical dispersing agents to deflocculate clays. The pre-treatment of the samples for grain size analysis using the Sedigraph consisted in removing the organic matter with hydrogen peroxide and dispersing aggregated particles with sodium hexametaphosphate.

Comparison of clay volumes obtained on the same samples with the Sedigraph and the laser microgranulometer suggests that the boundary between clay and silt should be at more than $2 \mu \mathrm{m}$, since the laser technique overestimates the amount of silt. The clay-silt boundary used for measurements with the laser microgranulometer was $6.2 \mu \mathrm{m}$ because that had the lowest mean squared error (Fig. 3).

\section{Geotechnical measurements}

Multiple geotechnical measurements were carried out on sediment samples. Moisture content was determined for PSM3 cores every $25 \mathrm{~cm}$ and every $1 \mathrm{~m}$ on borehole cores GDEC4-2 and GDEC8-2. One dimensional consolidation tests were performed using conventional oedometers and procedures for incremental loading from 1 to $1765 \mathrm{kPa}$ with ensuing loads doubled every $24 \mathrm{~h}$. The preconsolidation stress $\left(\sigma_{p}^{\prime}\right)$ of samples was calculated from the $e-\sigma^{\prime}{ }_{v}$ plot, where $e$ is the void ratio and $\sigma^{\prime}{ }_{v}$ the vertical effective stress. We used Pacheco Silva's method (Pacheco Silva 1970) because it 
relies on more objective criteria (Clementino 2005) and is not scale-dependent, in contrast to the Casagrande (Casagrande 1936) or the Onitsuka methods (Onitsuka et al. 1995). The compressibility $\left(C_{c}\right)$ of the sediment was calculated as the slope of the virgin compression line. The Overconsolidation Ratio $(O C R)$ was calculated as the ratio between the preconsolidation stress $\left(\sigma_{p}^{\prime}\right)$ and the vertical effective stress $\left(\sigma_{v}^{\prime}\right)$. The vertical effective stress can be calculated as:

$\sigma^{\prime}{ }_{v}=\int_{0}^{z}\left(\gamma(z)-\gamma_{w}(z)\right) d z$,

where $z$ is the in situ depth, $v$ is the bulk unit weight of the sediment and $\gamma_{w}$ is the unit weight of water.

Permeability tests were performed on each sample placed in oedometers at the end of successive loading stages, starting from $55 \mathrm{kPa}$ to $1765 \mathrm{kPa}$. The permeability coefficient $\left(\mathrm{k}\right.$ in $\left.\mathrm{m} \cdot \mathrm{s}^{-1}\right)$ was determined with the 'falling head method'. Peak undrained shear strengths $\left(S u_{p}\right)$ were obtained from laboratory vane shear tests, performed every 10 or $15 \mathrm{~cm}$ in all cores and boreholes on muddy sediment.

\section{D slope stability modelling}

Two slope profiles and two different types of sediment properties were used in a 1D slope stability assessment to investigate the importance of seafloor morphology versus sediment properties on slope instability. The main studied landslides took place in an open slope with little lateral changes in slope gradient, so edge effects can be ignored; therefore an infinite slope analysis was used to calculate the Factors of Safety (FOS) against failure. The calculation was carried out assuming infinite slope length in undrained conditions because the development of catastrophic failure, that is the most critical scenario, is expected to occur very rapidly, and will thus mobilise the parameters of the undrained sediment (Puzrin et al. 2016). The slope is considered stable when FOS is higher than 1. The FOS as a function of depth $(z)$ was calculated in static undrained conditions as:

$F O S=\left(\frac{\operatorname{su}(z)}{\sigma^{\prime}{ }_{v}(z) \sin \alpha \cos \alpha}\right)$,

where $S u$ is the undrained shear strength, $\sigma_{v}^{\prime}$ is the vertical effective stress calculated as in equation 1 and $\alpha$ is the slope angle.

\section{Results and interpretations}

\section{Physical and sedimentological properties}

Density and P-wave velocity values have a higher variability in mounded drifts and within moats than in hemipelagites and plastered drifts (Fig. 4). Density values range between 1.4 and $1.85 \mathrm{~g} \cdot \mathrm{cm}^{-3}$ in contourites and between 1.4 and $2.0 \mathrm{~g} \cdot \mathrm{cm}^{-3}$ in hemipelagites. General trends for both mounded and plastered drifts are slightly lower than trends for hemipelagites (Fig. 4). P-wave velocity values are 
similar in both types of sediment and typically increase from $1460 \mathrm{~m} \cdot \mathrm{s}^{-1}$ at the seabed to $1580 \mathrm{~m} \cdot \mathrm{s}^{-1}$ at 30 mbsf. Mounded drifts and hemipelagites from the slope have slightly higher and more scattered values, with many high peaks in the mounded drifts (Fig. 4). In moats (Fig. 1) sediments also have high and scattered P-wave velocity values ranging between 1505 and $1585 \mathrm{~m} \cdot \mathrm{s}^{-1}$ within the upper 9 mbsf (Fig. 4).

Contouritic muddy sediments (plastered drifts and muddy part of mounded drifts) are slightly finergrained than hemipelagic sediments. Muddy contourites have a mean grain size of 15-30 $\mu \mathrm{m}$, while the mean grain size values of hemipelagites from the slope and the basin range between 20 and 45 $\mu \mathrm{m}$ (Fig. 4). Contouritic and hemipelagic sediments are mostly muddy, although the mounded drifts contain sandy layers, in which the sand volume can reach up to $70 \%$, for instance at $12.5 \mathrm{~m}$ in core PSM3-CS009 (Fig. 5). The abundant sandy layers in the mounded drifts can explain the high peaks in P-wave velocity in this environment (Fig. 4). Hemipelagites in the basin are composed of 26-62\% clay, 28-61 \% silt and 10-15\% sand. Hemipelagites in the slope contain between 27 and 56 \% clay, 38-55 \% silt and 11-14 \% sand (Table 1 and Fig. 4). Sediments in the plastered drifts lack sand-rich layers because core PSM3-CS017 was collected in the lower part of the plastered drift at some distance from the shelf edge, which acts as a source for sandy material (Figs. 1 and 2). Clay content in the plastered drifts ranges between 45 and $64 \%$, with 31-39\% silt and 6-16 \% sand (Table 1 and Fig. 4). The muddy sections of the mounded drifts are composed of $35-60 \%$ clay, $26-50 \%$ silt and $7-19 \%$ sand (Table 1 and Fig. 4).

The moisture content in hemipelagites decreases from $95 \%$ at the seabed to $45 \%$ within the upper two mbsf (Fig. 4). Below 2 mbsf, moisture contents decrease gradually, remaining between 32 and 48 $\%$. Contourites have a higher variability in moisture content, varying between 123 and $49 \%$ near the seafloor. In general contouritic sediments tend to have slightly higher moisture contents than hemipelagites (Fig. 4). This is most noticeable for mounded drift sediments, which show a scattered moisture content trend (Fig. 4). Mounded drifts have the highest moisture content at about 14 mbsf and 20-24 mbsf, coinciding with the occurrence of zeolite minerals with high water retention capabilities (Miramontes 2016). Overall, sediments in the moat have the lowest moisture contents with values varying between 35 and $60 \%$ (Fig. 4). The moisture contents of mounded and plastered drifts mainly range between 40 and $64 \%$, comparable to hemipelagites (Fig. 4).

\section{Consolidation state, permeability and compressibility}

The oedometer tests carried out on samples from 7 cores in the Pianosa Contourite Depositional System showed that sediment drifts are normally consolidated to underconsolidated, with overconsolidation ratios (OCR) ranging between 0.5 and 1.1 (Fig. 6). Higher OCR values (1.3-2.2), found within the upper 2 mbsf (Fig. 6), can be explained by an apparent overconsolidation, common 
in surface sediments (Sultan et al. 2000). OCR values in core PSM3-CS003, collected in a moat (Fig. 1), range between 1.2 and 2.1 (Fig. 6), corresponding to slightly overconsolidated sediments. Hemipelagites are normally consolidated to underconsolidated, with OCR values around 0.7 (Fig. 6). The permeability of hemipelagites varies within the same range as that of contourites (Fig. 6). In contourites, values of the natural permeability coefficient $\left(k_{i}\right)$ are estimated to range between $5 \cdot 10^{-8}$ $\mathrm{m} \cdot \mathrm{s}^{-1}$ (extreme high values at the surface) and $3 \cdot 10^{-9} \mathrm{~m} \cdot \mathrm{s}^{-1}$, although most of the samples have $k_{i}$ values between $4 \cdot 10^{-9}$ and $9 \cdot 10^{-9} \mathrm{~m} \cdot \mathrm{s}^{-1}$. Values of $k i$ for the sediment from the moat are lower than in the sediment from the contourite drifts at the same depth below the seafloor. In hemipelagites, the natural permeability coefficient ranges between $9 \cdot 10^{-9}$ and $2 \cdot 10^{-8} \mathrm{~m} \cdot \mathrm{s}^{-1}$ (Fig. 6).

The high compression indices $\left(C_{c}\right)$ and $k_{i}$ values found in mounded drifts between 16 and 20 mbsf correspond to a particular sediment layer that contains zeolites, as already mentioned above (Miramontes 2016). Sediments from moats are less compressible than sediments from contourite drifts (Fig. 6). Hemipelagites have compression indices slightly lower than most of the contouritic samples and range between 0.2 and 0.4 (apart from a sample at about 1 mbsf with higher $C_{c} ;$ Fig. 6).

Moat sediments are slightly overconsolidated and have lower in situ permeability. Both properties suggest that the moat is an environment dominated by erosive processes. No major differences are found between hemipelagites and contourites, although contourites seem to be slightly more compressible than hemipelagites.

\section{Undrained shear strength}

The peak undrained shear strengths $\left(S u_{p}\right)$ obtained from laboratory vane shear tests tend to increase with depth in a similar fashion both in hemipelagic and contouritic sediments. In general, $S u_{p}$ increases linearly from $3 \mathrm{kPa}$ at the seafloor to $40 \mathrm{kPa}$ at $30 \mathrm{mbsf}$ (Fig. 7). This trend is punctuated by strong oscillations in the 10 and $50 \mathrm{kPa}$ range between 14 and $28 \mathrm{mbsf}$. Moat sediments have higher $S u_{p}$ values (Fig. 7). Peak undrained shear strengths in the plastered drift are lower than in most of the hemipelagites from the slope and mounded drift sediments (Fig. 7).

\section{Slope stability analysis}

Comparison of the geotechnical properties of hemipelagic and contouritic sediment shows that hemipelagites from the slope have a higher density (Fig. 4) and higher undrained shear strength (Fig. 7) than the plastered drift sediments. These two types of sediments occur in different areas on the flanks within the basin. Distinct sedimentation processes shaped the two flanks of the basin differently. The western flank has an overall gentle slope of $2-3^{\circ}$, although a zone of higher slope gradient $\left(5^{\circ}\right)$ is related to the presence of a small plastered drift at 300-400 m water depth (Figs. 2 and $8 \mathrm{a}$ ). The bathymetric profile along this flank is thus generally straight (Fig. 8a). In contrast, the 
eastern flank in the southern part of the Pianosa Ridge has steeper slope gradients, caused by the presence of convex-shaped contourites (plastered drift) and the moats generated by bottom currents at the foot of the slope (Fig. 8a). In the upper part of the plastered drift the slope gradient is low $1-3^{\circ}$, but it becomes much steeper in the middle and lower slopes, reaching $11^{\circ}$ in the moat (Fig. 8a).

A 1D slope stability analysis using the properties of the hemipelagic sediment from the slope and the properties of the plastered drift with different slope angles was carried out to investigate which factor plays the most important role in slope stability: the seafloor morphology (angle $\alpha$ ) or the sediment properties (undrained shear strength, Su, and unit weight, $\gamma$ ). The slope stability assessment shows that both the hemipelagic and contouritic sediment are stable (FOS $>1)$ for slope angles lower than $5^{\circ}$ (Fig. 9), which are typical values found in slopes mainly composed of hemipelagites (Fig. 8a). On the other hand, both hemipelagites and plastered drifts would be unstable $(\mathrm{FOS}<1)$ for slope angles higher than $8^{\circ}$ (Fig. 9). The zone upslope of the moat in a plastered drift usually has steep slopes that can be higher than $11^{\circ}$ (Fig. 8a). Therefore, this zone is the most critical one, no matter what the type of sediment.

\section{Discussion}

Sedimentological and geotechnical properties of contourites and hemipelagites

The present study in the Corsica Trough shows some differences in the intrinsic sedimentological and geotechnical properties of contourites and hemipelagites, especially between the plastered drift sediments and hemipelagites from the slope. The plastered drift has finer sediment (a higher clay fraction; Fig. 5), lower density (Fig. 4), higher moisture content, higher compressibility (also the mounded drift; Fig. 6) and lower undrained shear strength (Fig. 7). However, no major differences were observed between the undrained shear strength of the plastered drift sediments and that of the hemipelagites from the bottom of the basin. All the analysed sediments also had similar permeability coefficients (Fig. 6).

Contourite depositional systems may contain different types of sediments with distinct geotechnical properties. For instance, mounded drifts have abundant poorly sorted sandy layers, which are absent in the lower part of the plastered drift (Fig. 5). The moat is the environment of the contourite depositional system that differs the most from the contourite drifts and the hemipelagites. It is composed of coarser material and due to erosive processes has different inherited properties: the sediments are overconsolidated, with a low moisture content, low permeability (Fig. 6) and high undrained shear strength (Fig. 7). Many oceanographic processes can erode sediment in marine systems: geostrophic currents (as in the present study), internal waves, tidal currents, surface waves, cascades of dense water, eddies, deep-sea storms, rogue waves and tsunami-related currents (Shanmugam 2013; Rebesco et al. 2014). The subaqueous erosion of the seafloor changes the 
geotechnical properties of the sediment. Moreover, the fine-grained sediment put in suspension after the erosion may be transported and sorted by bottom currents, thus influencing the composition and properties of the final deposit.

\section{Potential causal factors of slope instability in contourites}

Although contourites generally accumulate on gentle slopes $\left(<1^{\circ}\right.$; Laberg and Camerlenghi 2008), they can also be formed on steep slopes and generate, due to their particular internal architecture, zones with high slope angles (Figs. 8a and 10). Plastered drifts commonly develop on continental slopes, right below the continental shelf edge or below terraces (Hernández-Molina et al. 2016). When the evolution of continental slopes is mainly controlled by hemipelagic and turbiditic sedimentation (such as the western flank of the Corsica Trough), it results in a linear bathymetric cross-section profile (Figs. 8a and 10). On the contrary, in contourite systems, bottom currents can induce preferential sediment deposition at mid-slope, forming a plastered drift with a steep downslope flank (Figs. 8a and 10). The resulting convex slope profile is, independently of the sediment properties, potentially more unstable than the typical slope profile observed where hemipelagic and turbiditic sedimentation dominate (Figs. 8 and 9). Despite the observed differences in geotechnical properties between hemipelagites from the slope and the plastered drift sediments, the slope stability analysis shows that the main factor controlling the development of submarine landslides in contourites is the morphology of the plastered drift (Fig. 9).

The plastered drift of the Pianosa Ridge was affected by four submarine landslides during the PlioQuaternary period that were the largest mass failures in the area (Fig. 1a; Miramontes et al. 2016a). Bottom currents play a very important role in shaping continental slopes and in creating convex seafloor morphologies that are more susceptible to failure. Therefore, the generation of a plastered drift can be a predisposing factor of slope instability. Puzrin et al. (2015) proposes that the development of large underwater landslides may be related to shear band propagation in nonlinear slopes (as in a plastered drift). In their analysis they show that the growth of a shear band is more dependent on the shape of the slope than on its inclination. Although in the present study we used the peak undrained shear strength of sediments for the slope stability analysis, Miramontes (2016) observed a sediment layer with a strain softening behaviour in the study area where shear band propagation could occur. Taken together with the results of Puzrin et al. (2015), the results of the present study suggest that weak zones may initially appear in the steepest part of contourites where the combined action of gravity and erosion can generate a weak zone that may propagate, developing large failure surfaces. This view is supported by common observations of erosional features and landslide headscarps at the foot of plastered drifts, e.g.; in the Uruguayan margin 
(Hernández-Molina et al. 2016), in the Argentinean margin (Preu et al. 2013) and in the Alboran Sea (Ercilla et al. 2016).

\section{Conclusions}

The Corsica Trough is a confined basin in the Northern Tyrrhenian Sea with an eastern margin dominated by contouritic and mass transport processes and a western margin dominated by turbiditic and hemipelagic processes. This asymmetry allowed a comparison between the sedimentological and geotechnical properties of contourites and hemipelagites, as well as between the seafloor morphologies and slope stability of different margin settings.

In the Corsica Trough, contourite drifts could be separated in two main groups with different properties: mounded drifts and plastered drifts. The mounded drifts contain more sandy layers related to periods of faster bottom currents. These sandy layers are more highly developed in zones close to the moat. Moats differ from a sedimentological point of view to the muddy contourite drifts and hemipelagites because they are dominated by erosive processes, they are slightly overconsolidated, and contain coarser material of lower permeability and compressibility. Plastered drifts are the contourites that differ the most from the hemipelagites found in the slope. Plastered drifts have lower density, finer material, higher compressibility (like the mounded drift) and lower undrained shear strength than hemipelagites.

Our findings suggest that the main factor controlling slope instability in contourites is the seafloor morphology, i.e. the steep slopes and a convex shape. Slope stability analyses along the western flank of the Corisca Trough show that both sediments, hemipelagites and contourites, would be stable. On the other hand, both types of sediment would be unstable in the lower part of the plastered drift, where the slope angle is about $11^{\circ}$. Moreover, bottom currents often generate erosion at the foot of plastered drifts and may trigger submarine landslides by undercutting the slope. Slope failures at the lower part of plastered drifts have been observed along many continental margins. A better understanding of the formation and evolution of this type of drifts could provide very valuable information about submarine geohazards.

\section{Acknowledgements}

We would like to thank the Captain and the crew of the CORFAN, CORFAN 2, SIGOLO, GOLODRILL, PAMELA-PAPRICA, PRISME2 and PRISME3 surveys. We are grateful to Marzia Rovere, Fabio Trincardi, Andrea Gallerani and Patrizia Giordano for the grain size analysis at the CNR-ISMAR laboratories and to the Collège Doctoral International of the Université Européene de Bretagne and the Conseil Régional de Bretagne for having awarded E. Miramontes with a travel grant during her stay at CNRISMAR. The thesis of E. Miramontes and the cruise PRISME2-PAPRICA were co-funded by TOTAL and 
Ifremer as part of the PAMELA (Passive Margins Exploration Laboratories) scientific project. We are grateful to the anonymous reviewers for their valuable suggestions that improved the manuscript.

\section{References}

Baeten NJ, Laberg JS, Vanneste M, Forsberg CF, Kvalstad TJ, Forwick M, Vorren TO and Haflidason H (2014) Origin of shallow submarine mass movements and their glide planes-sedimentological and geotechnical analyses from the continental slope off northern Norway. Journal of Geophysical Research-Earth Surface 119: 2335-2360. doi: 10.1002/2013jf003068

Bryn P, Berg K, Stoker MS, Haflidason H and Solheim A (2005a) Contourites and their relevance for mass wasting along the Mid-Norwegian Margin. Marine and Petroleum Geology 22: 85-96. doi: 10.1016/j.marpetgeo.2004.10.012

Bryn P, Berg K, Forsberg CF, Solheim A and Kvalstad TJ (2005b) Explaining the Storegga slide. Marine and Petroleum Geology 22: 11-19. doi: 10.1016/j.marpetgeo.2004.12.003

Calvès G, Toucanne S, Jouet G, Charrier S, Thereau E, Etoubleau J, Marsset T, Droz L, Bez M, Abreu V, Jorry S, Mulder T and Lericolais G (2013) Inferring denudation variations from the sediment record; an example of the last glacial cycle record of the Golo Basin and watershed, East Corsica, western Mediterranean sea. Basin Research 25: 197-218.

Casagrande A (1936) The determination of the pre-consolidation load and its practical significance. In: Casagrande A (ed) Proceedings of 1st International Soil Mechanics and Foundation Engineering Conference, Cambridge, Mass., 22-26 June 1936. Graduate School of Engineering, Harvard University, Cambridge, Mass. 3, 60-64.

Cattaneo A (2013a) PRISME2 cruise, RV L'Atalante, http://dx.doi.org/10.17600/13010050.

Cattaneo A (2013b) PRISME3 cruise, RV Pourquoi pas ?, http://dx.doi.org/10.17600/13030060.

Cattaneo A and Jouet G (2013) PAMELA-PAPRICA cruise, RV L'Atalante, http://dx.doi.org/10.17600/13010300.

Cattaneo A, Jouet G, Charrier S, Thereau E, Riboulot V (2014) Submarine landslides and contourite drifts along the Pianosa Ridge (Corsica Trough, Mediterranean Sea). In: Krastel S, et al (eds), Submarine Mass Movements and their Consequences 37. Springer, Dordrecht, pp 435-445.

Clementino RV (2005) Discussion of "An oedometer test study on the preconsolidation stress of glaciomarine clays". Canadian Geotechnical Journal 42: 972-974. doi: 10.1139/t05-010

Deptuck ME, Piper DJW, Savoye B and Gervais A (2008) Dimensions and architecture of late Pleistocene submarine lobes off the northern margin of East Corsica. Sedimentology 55: 869898. doi: 10.1111/j.1365-3091.2007.00926.x

Ercilla G, Juan C, Hernandez-Molina FJ, Bruno M, Estrada F, Alonso B, Casas D, Farran M, Llave E, Garcia M, Vazquez JT, D'Acremont E, Gorini C, Palomino D, Valencia J, El Moumni B and Ammar 
A (2016) Significance of bottom currents in deep-sea morphodynamics: An example from the Alboran Sea. Marine Geology 378: 157-170. doi: 10.1016/j.margeo.2015.09.007

Gervais A, Savoye B, Mulder T and Gonthier E (2006) Sandy modern turbidite lobes: a new insight from high resolution seismic data. Marine and Petroleum Geology 23(4): 485-502. doi : 10.1016/j.marpetgeo.2005.10.006

Hernández-Molina FJ, Llave E and Stow DAW (2008) Continental slope contourites. In: Rebesco M, Camerlenghi A (eds) Contourites. Developments in Sedimentology 60. Elsevier, pp 379-408.

Hernández-Molina FJ, Soto M, Piola AR, Tomasini J, Preu B, Thompson P, Badalini G, Creaser A, Violante RA, Morales E, Paterlini M and De Santa Ana H (2016) A contourite depositional system along the Uruguayan continental margin: Sedimentary, oceanographic and paleoceanographic implications. Marine Geology 378: 333-349. doi: 10.1016/j.margeo.2015.10.008

Hübscher C, Betzler C and Reiche S (2016) Seismo-stratigraphic evidences for deep base level control on middle to late Pleistocene drift evolution and mass wasting along southern Levant continental slope (Eastern Mediterranean). Marine and Petroleum Geology 77: 526-534. doi: 10.1016/j.marpetgeo.2016.07.008

Krastel S, Wefer G, Hanebuth TJJ, Antobreh AA, Freudenthal T, Preu B, Schwenk T, Strasser M, Violante R, Winkelmann D and Party MSS (2011) Sediment dynamics and geohazards off Uruguay and the de la Plata River region (northern Argentina and Uruguay). Geo-Marine Letters 31: 271-283. doi: 10.1007/s00367-011-0232-4

Laberg JS and Camerlenghi A (2008) The significance of contourites for submarine slope stability. In: Rebesco M, Camerlenghi A (eds) Contourites. Developments in Sedimentology 60. Elsevier, pp 537-556.

Laberg JS, Dahlgren T, Vorren TO, Haflidason H and Bryn P (2001) Seismic analyses of cenozoic contourite drift development in the Northern Norwegian Sea. Marine Geophysical Researches 22: 401-416. doi: 10.1023/a:1016347632294

Laberg JS, Vorren TO, Mienert J, Evans D, Lindberg B, Ottesen D, Kenyon NH and Henriksen S (2002) Late Quaternary palaeoenvironment and chronology in the Trænadjupet Slide area offshore Norway. Marine Geology 188: 35-60. doi: 10.1016/s0025-3227(02)00274-8

Laberg JS, Baeten NJ, Vanneste M, Forsberg CF, Forwick M and Haflidason H (2016) Sediment Failure Affecting Muddy Contourites on the Continental Slope Offshore Northern Norway: Lessons Learned and Some Outstanding Issues. Submarine mass movements and their consequences, Springer, pp 281-289. doi: 10.1007/978-3-319-20979-1_28 
Lüdmann T, Wiggershaus S, Betzler C and Hübscher C (2012) Southwest Mallorca Island: A cool-water carbonate margin dominated by drift deposition associated with giant mass wasting. Marine Geology 307: 73-87. doi: 10.1016/j.margeo.2011.09.008

Marani M, Argnani A, Roveri M and Trincardi F (1993) Sediment drifts and erosional surfaces in the central Mediterranean - seismic evidence of bottom-current activity. Sedimentary Geology 82: 207-220. doi: 10.1016/0037-0738(93)90122-I

Miramontes E (2016) Submarine landslides in the Northern Tyrrhenian Sea and relationship with the contouritic and turbiditic deposits: morphology, stratigraphy, geotechnics and modelling. Dissertation, Université de Bretagne Occidentale.

Miramontes E, Cattaneo A, Jouet G and Garziglia S (2016a) Implications of Sediment Dynamics in Mass Transport along the Pianosa Ridge (Northern Tyrrhenian Sea). In: Lamarche, G., Mountjoy, J. (Eds.), Submarine mass movements and their consequences 30. Springer, Dordrecht, pp 301-309. doi: /10.1007/978-3-319-20979-1_30

Miramontes E, Cattaneo A, Jouet G, Thereau E, Thomas $Y$, Rovere M, Cauquil E and Trincardi $F$ (2016b) The pianosa contourite depositional system (northern Tyrrhenian Sea): drift morphology and plio-quaternary stratigraphic evolution. Marine Geology 378: 20-42. doi: 10.1016/j.margeo.2015.11.004

Onitsuka K, Hong Z, Hara Y and Shigeki Y (1995) Interpretation of oedometer test data for natural clays. Journal of the Japanese Geotechnical Society, Soils and Foundations, 35(3): 61-70.

Pacheco Silva F (1970) A new graphical construction for determination of the pre-consolidation stress of a soil sample. In: Proceedings of the 4th Brazilian Conference on Soil Mechanics and Foundation Engineering, Rio de Janeiro, Brazil, 2(1), pp 225-232.

Preu B, Hernandez-Molina FJ, Violante R, Piola AR, Paterlini CM, Schwenk T, Voigt I, Krastel S and Spiess V (2013) Morphosedimentary and hydrographic features of the northern Argentine margin: the interplay between erosive, depositional and gravitational processes and its conceptual implications. Deep-Sea Research Part I-Oceanographic Research Papers 75: 157174. doi: 10.1016/j.dsr.2012.12.013

Principaud M, Mulder T, Gillet H and Borgomano J (2015) Large-scale carbonate submarine masswasting along the northwestern slope of the Great Bahama Bank (Bahamas): Morphology, architecture, and mechanisms. Sedimentary Geology 317: 27-42. doi: 10.1016/j.sedgeo.2014.10.008

Puzrin AM, Gray T and Hill AJ (2015) Significance of the actual non-linear slope geometry for catastrophic failure in submarine landslides. Proc. R. Soc. A, Math. Phys. Engng Sci. 471, No. 2175 : $1-25$. 
Puzrin AM, Germanovich LN and Friedli B (2016) Shear band propagation analysis of submarine slope stability. Géotechnique 66(3): 188-201. doi: 10.1680/jgeot.15.LM.002

Rebesco M, Hernández-Molina FJ, Van Rooij D and Wåhlin A (2014) Contourites and associated sediments controlled by deep-water circulation processes: state-of-the-art and future considerations. Marine Geology 352: 111-154.

Roveri M (2002) Sediment drifts of the Corsica Channel, northern Tyrrhenian Sea. In: Stow DAV, Pudsey CJ, Howe JA, Faugères J-C, Viana AR (eds) Deep-Water Contourite Systems: Modern Drifts and Ancient Series, Seismic and Sedimentary Characteristics. Geological Society, London, Memoirs, 22, pp 191-208.

Savoye B (1998) CORFAN cruise, RV L'Europe, http://dx.doi.org/10.17600/98060110.

Savoye B (2001) CORFAN 2 cruise, RV Le Suroît, http://dx.doi.org/10.17600/1020030.

Savoye B (2008) SIGOLO cruise, RV Le Suroît, http://dx.doi.org/10.17600/8020110.

Shanmugam G (2013) Modern internal waves and internal tides along oceanic pycnoclines: Challenges and implications for ancient deep-marine baroclinic sands. AAPG bulletin 97(5): 799-843.

Stow DAV and Tabrez AR (1998) Hemipelagites: Processes, facies and model. Geological Society, London, Special Publications 129: 317-337.

Stow DAV and Faugères JC (2008) Contourite facies and the facies model. In: Rebesco $M$, Camerlenghi A (eds) Contourites. Developments in Sedimentology 60. Elsevier, pp 223-256.

Sultan N, Cochonat P, Dennielou B, Bourillet J-F, Savoye B, Colliat JL (2000) Surconsolidation apparente et pression osmotique dans un sédiment marin. Comptes Rendus de l'Académie des Sciences-Series // A-Earth and Planetary Science 331(5): 379-386. doi.org/10.1016/S12518050(00)01419-1

Tournadour E, Mulder T, Borgomano J, Hanquiez V, Ducassou E and Gillet H (2015) Origin and architecture of a mass transport complex on the northwest slope of Little Bahama Bank (Bahamas): relations between off-bank transport, bottom current sedimentation and submarine landslides. Sedimentary Geology 317: 9-26. doi: 10.1016/j.sedgeo.2014.10.003

Vanneste M, Mienert J and Bunz S (2006) The Hinlopen slide: a giant, submarine slope failure on the northern Svalbard margin, Arctic Ocean. Earth and Planetary Science Letters 245: 373-388. doi: 10.1016/j.epsl.2006.02.045

Verdicchio $G$ and Trincardi F (2008) Mediterranean shelf-edge muddy contourites: examples from the Gela and South Adriatic basins. Geo-Marine Letters 28: 137-151. doi: 10.1007/s00367-0070096-9

Wilson CK, Long D and Bulat J (2004) The morphology, setting and processes of the Afen Slide. Marine Geology 213: 149-167. doi: 10.1016/j.margeo.2004.10.0054 


\section{Figure captions}

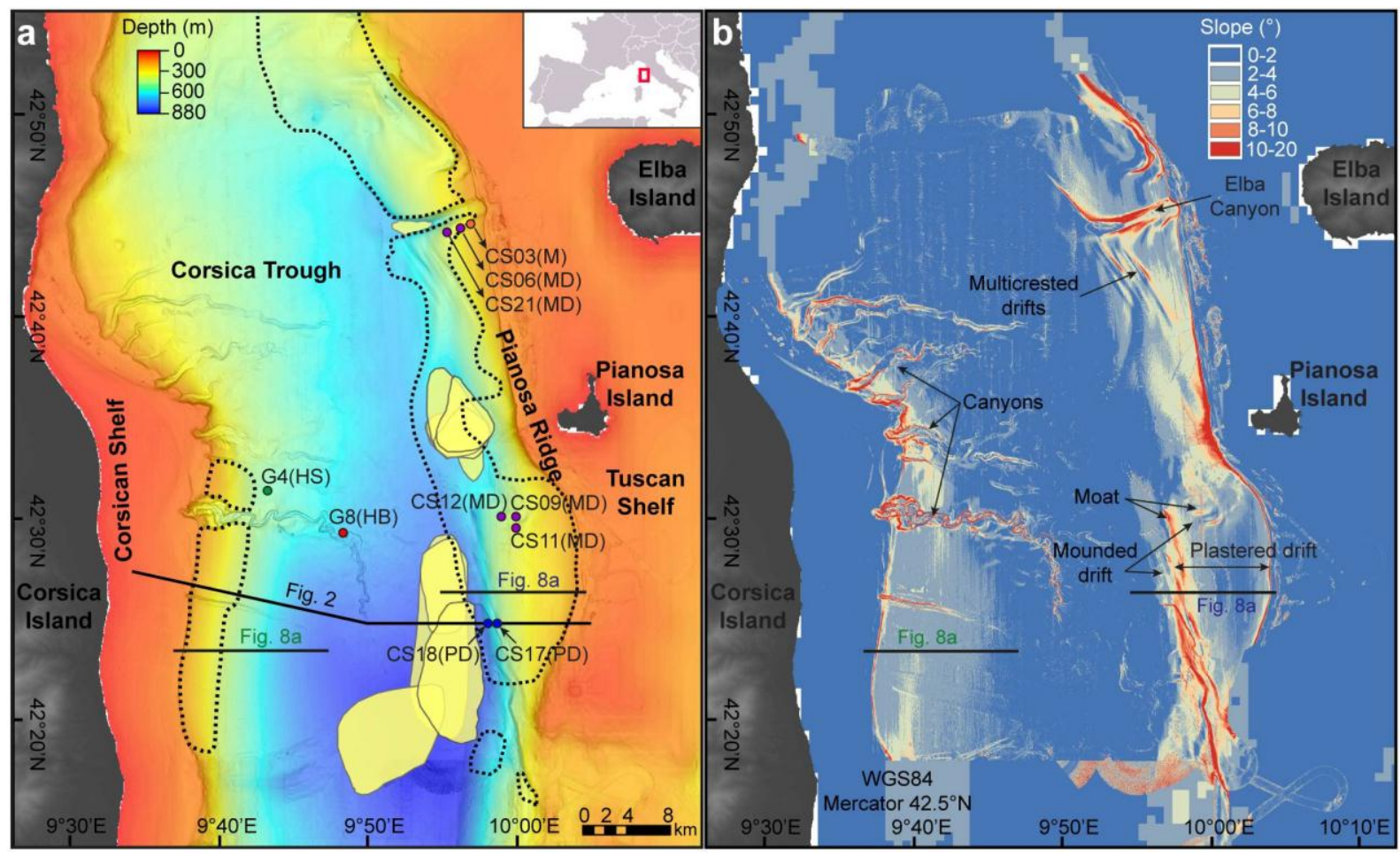

Fig. 1 a Bathymetric map of the Corsica Trough with the location of contourites (outlined with dashed lines), mass transport deposits (represented with yellow polygons), Calypso piston cores and boreholes. The colours of the dots indicate the different environments: Hemipelagite-Slope (HS) represented in green, Hemipelagite-Basin (HB) in red, Mounded Drift (MD) in purple, Plastered Drift (PD) in blue and Moat (M) in orange. The names of the boreholes and cores have been shortened to improve the readability (G4= GDEC4-2; G8= GDEC8-2, CSX= PSM3-CSOX). b Slope map of the Corsica Trough 


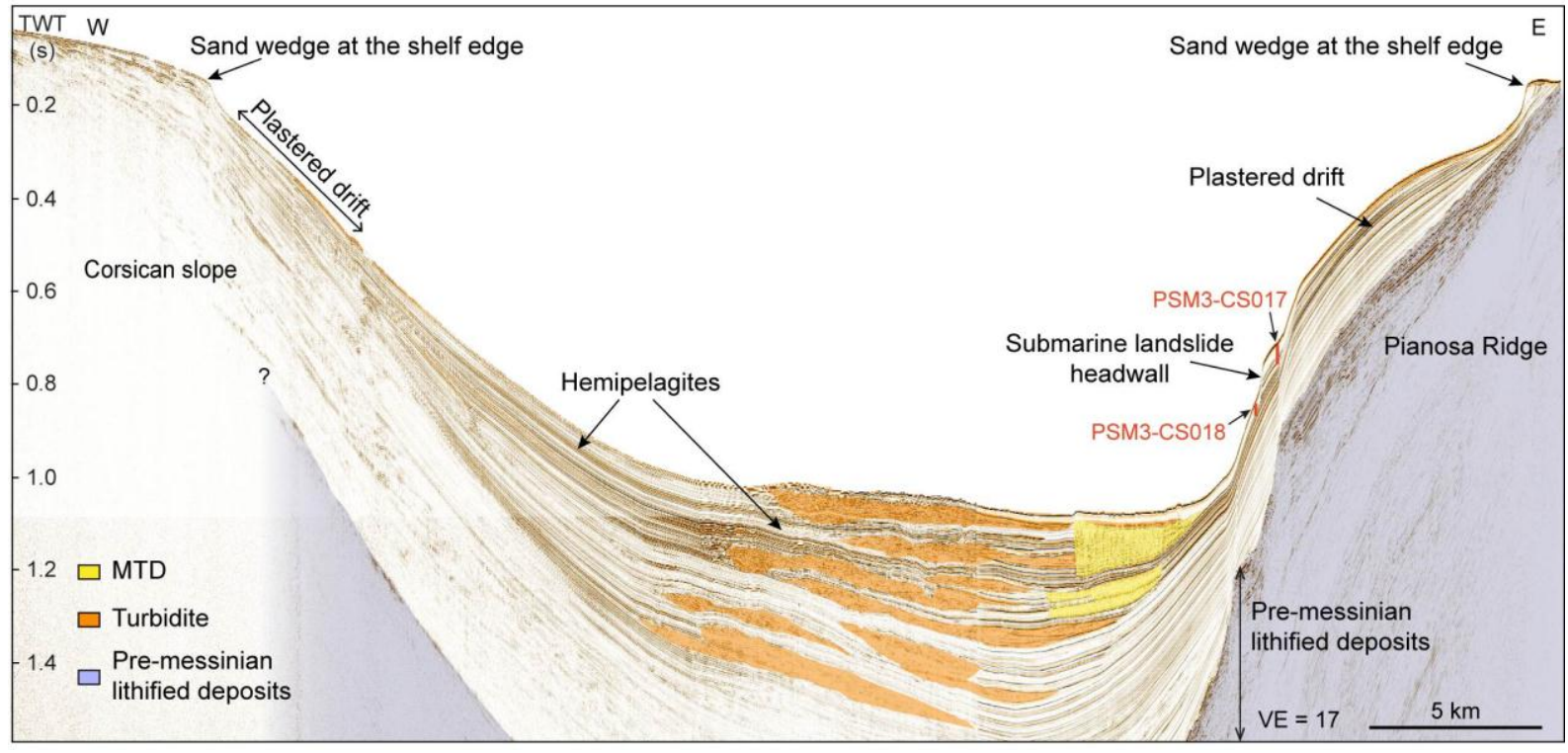

Fig. 2 Composite of multi-channel high resolution mini GI gun seismic reflection profiles SigoloMC069, Sigolo-MC054 and PSM2-HR033, showing the asymmetry of the basin and the location of cores PSM3-CS017 and PSM3-CS018 (plastered drift). MTD: Mass Transport Deposit. See Fig. 1 for location

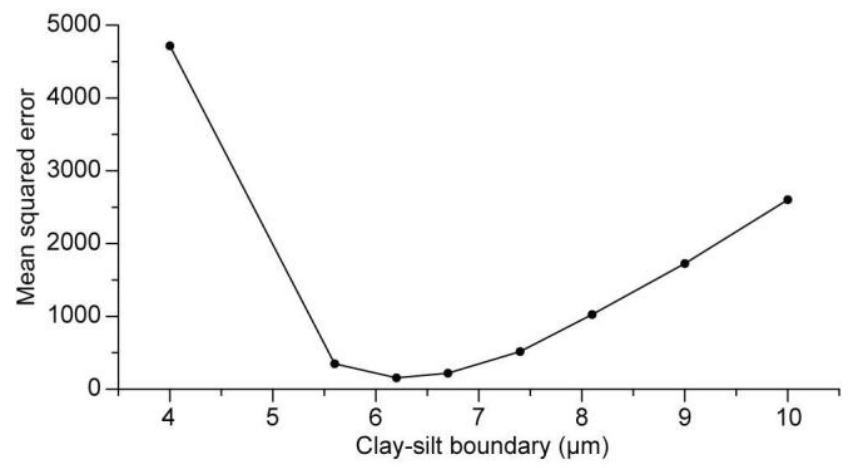

Fig. 3 Mean squared error of the clay volume measured with a Sedigraph 5100 and with Coulter LS200 laser microgranulometer in function of the established clay-silt boundary. The boundary at 6.2 $\mu \mathrm{m}$ presents the lowest mean squared error and it was thus chosen to calculate clay volumes from measurements carried out with the laser microgranulometer 

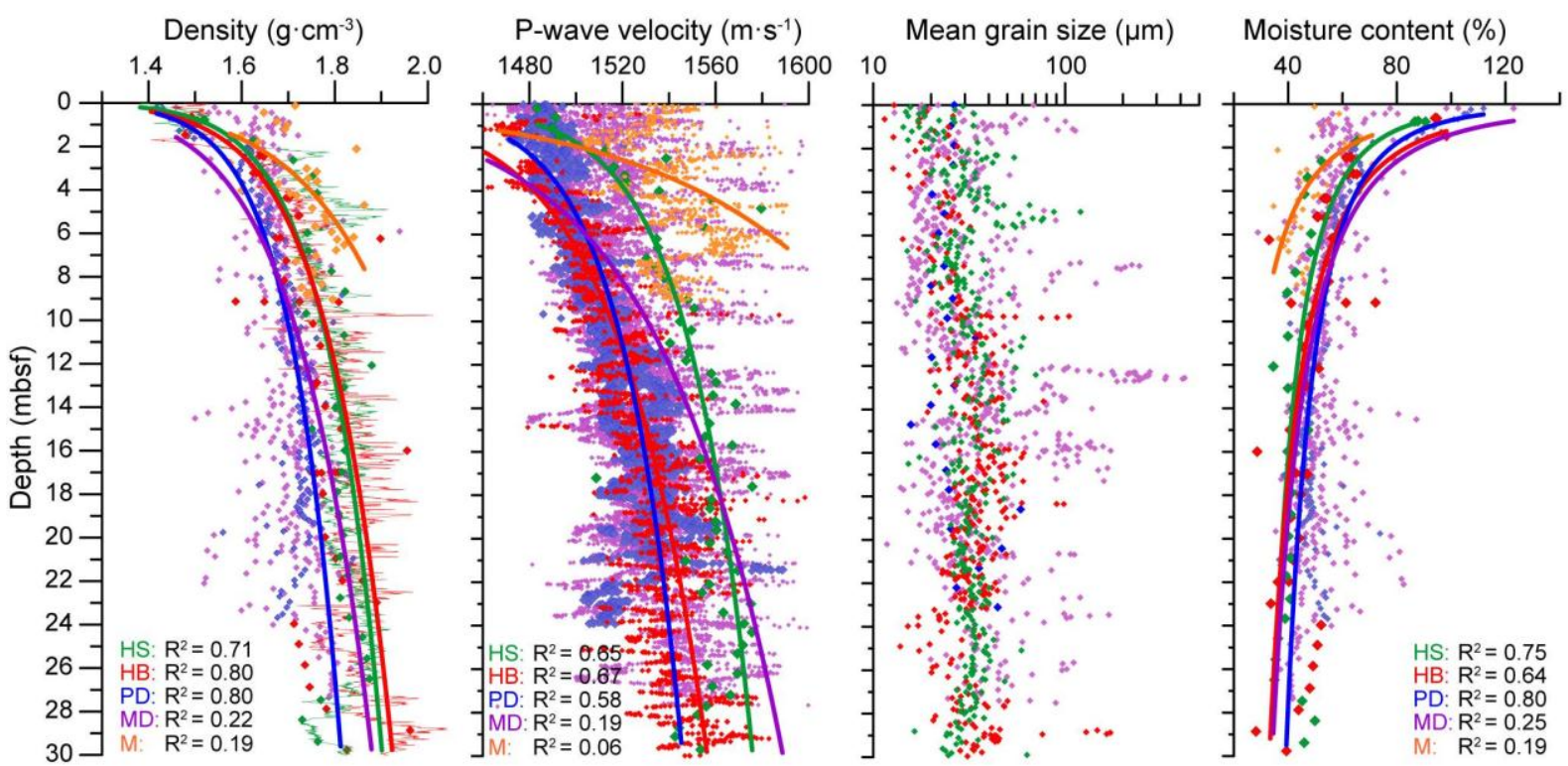

Fig. 4 From left to right: Density obtained from moisture content (diamonds) and MSCL (lines), Pwave velocity from MSCL (moat, plastered drift, mounded drift and hemipelagite-basin) and celerimeter (hemipelagite-slope), mean grain size and moisture content. HS: Hemipelagite Slope (GDEC4-2), HB: Hemipelagite Basin (GDEC8-2); PD: Plastered Drift (PSM3-CS017 and PSM3-CS018); MD: Mounded Drift (PSM3-CS006, PSM3-CS009, PSM3-CS011, PSM3-CS012 and PSM3-CS021); M: Moat (PSM3-CSO03). Best fit curves are displayed for each type of sediment. See Fig. 1 for core location 


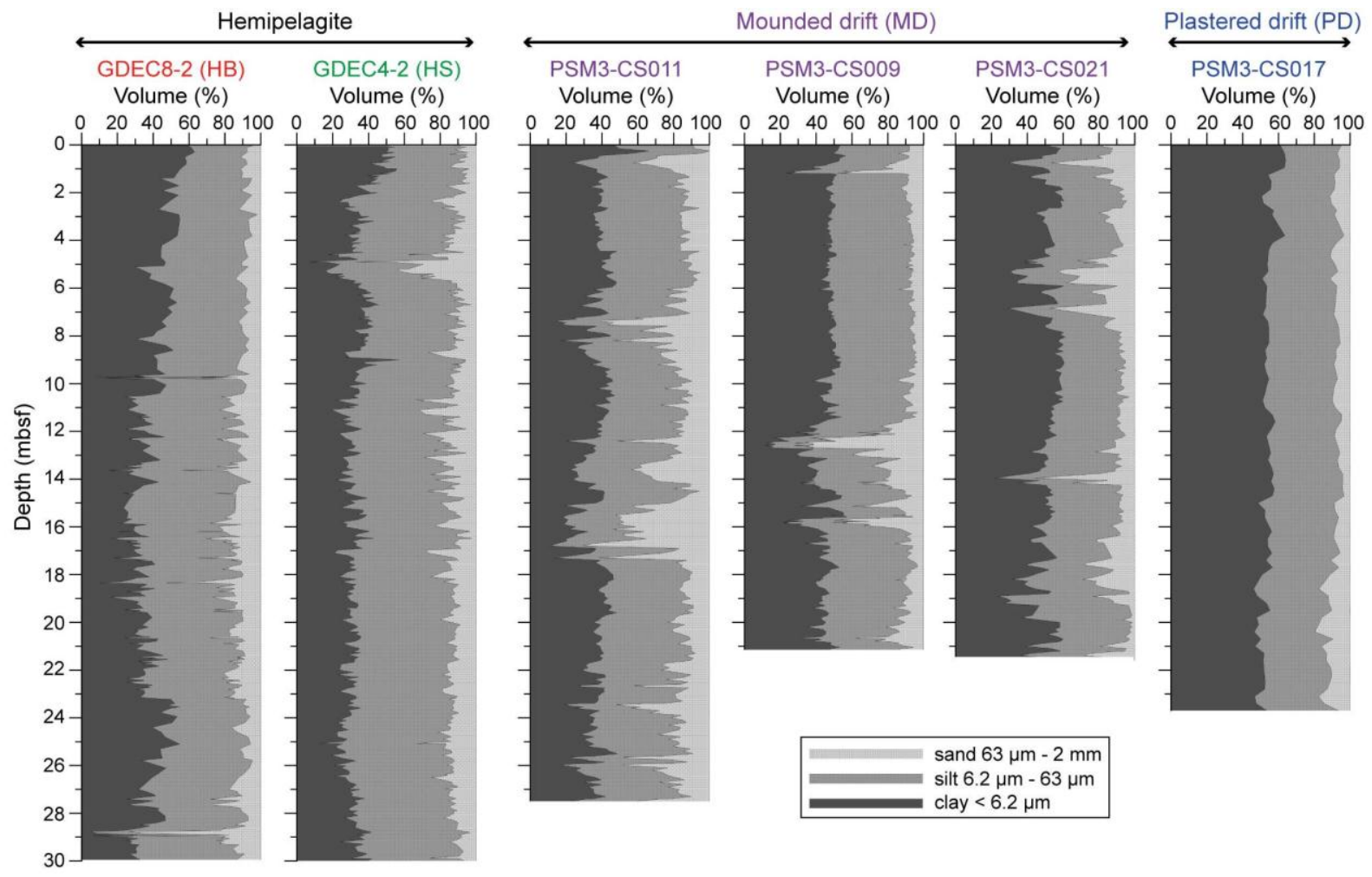

Fig. 5 Percent volumes of sand, silt and clay of boreholes GDEC8-2 (Hemipelagite Basin, HB) and GDEC4-2 (Hemipelagite Slope, HS) and Calypso piston cores PSM3-CS011, PSM3-CS009, PSM3-CS021 (Mounded Drifts, MD) and PSM3-CS017 (Plastered Drift, PD). Note that core PSM3-CS017 (plastered drift) is very homogeneous compared to the other three sediment cores from mounded drifts, it is mainly composed of mud with clay contents between 45 and $64 \%$. See Fig. 1 for core location 


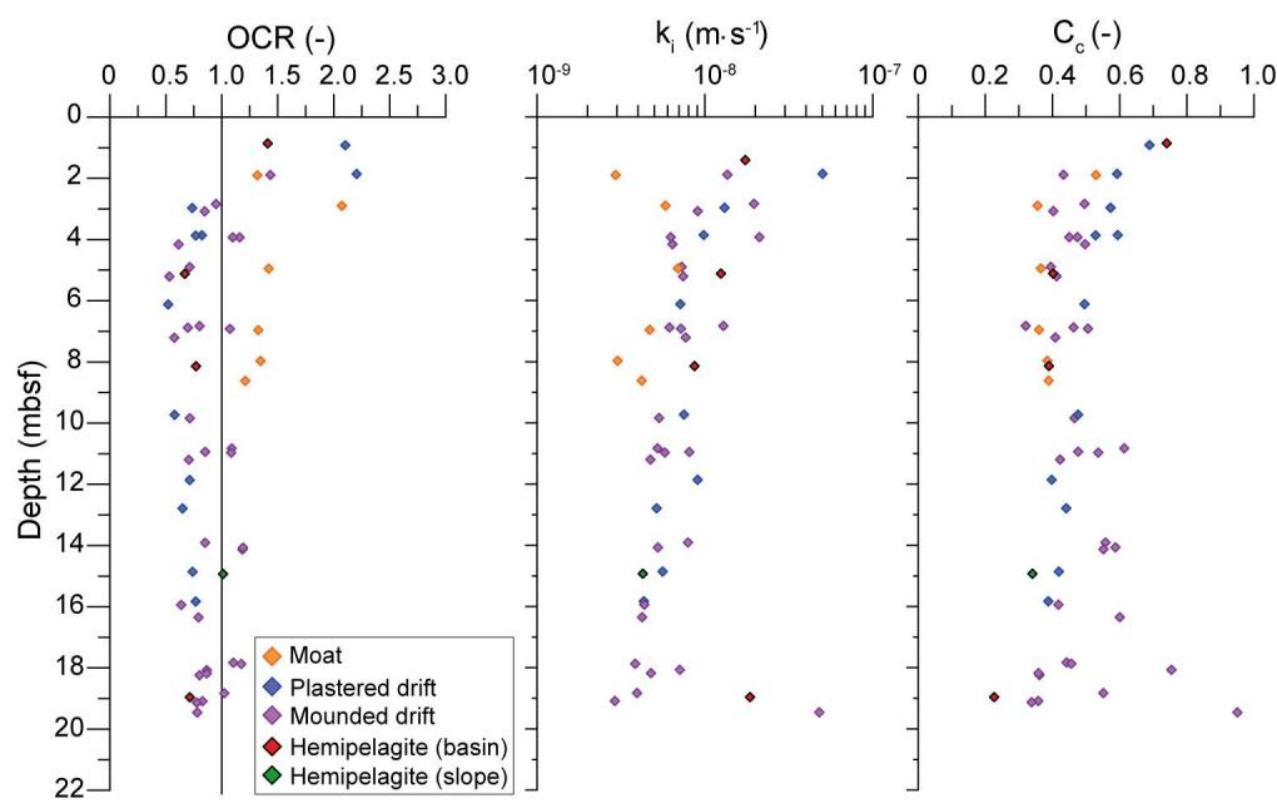

Fig. 6 Overconsolidation ratio $(O C R)$, natural permeability coefficient $\left(k_{i}\right)$ and compression index $\left(C_{c}\right)$ of 7 cores from the Pianosa Contourite Depositional System and 2 borehole cores of hemipelagites: moat (PSM3-CS003), plastered drift (PSM3-CS017 and PSM3-CS018), mounded drift (PSM3-CS006, PSM3-CS009, PSM3-CS012 and PSM3-CS021), hemipelagite-basin (GDEC8-2) and hemipelagite-slope (GDEC4-2). OCR values have been calculated using the Pacheco Silva's method (Pacheco Silva, 1970). See Fig. 1 for core location 


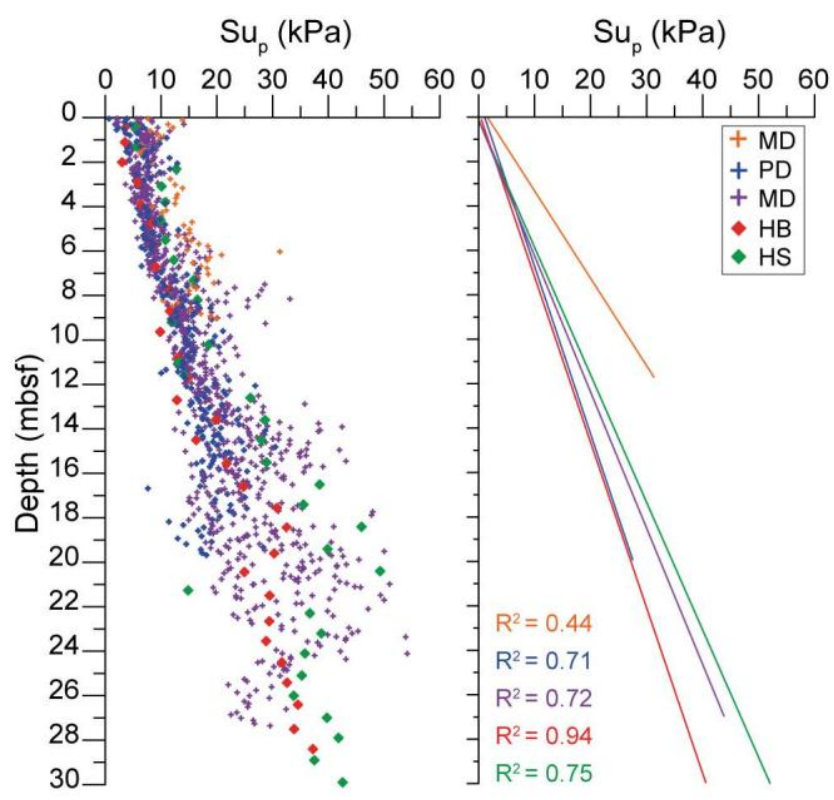

Fig. 7 Peak undrained shear strength of hemipelagites (HS: Hemipelagite Slope; HB: Hemipelagite Basin) and contourites (PD: Plastered Drift; MD: Mounded Drift; M: Moat) obtained using laboratory vane shear tests. The linear fits to the vane shear test data are presented in the right graph.
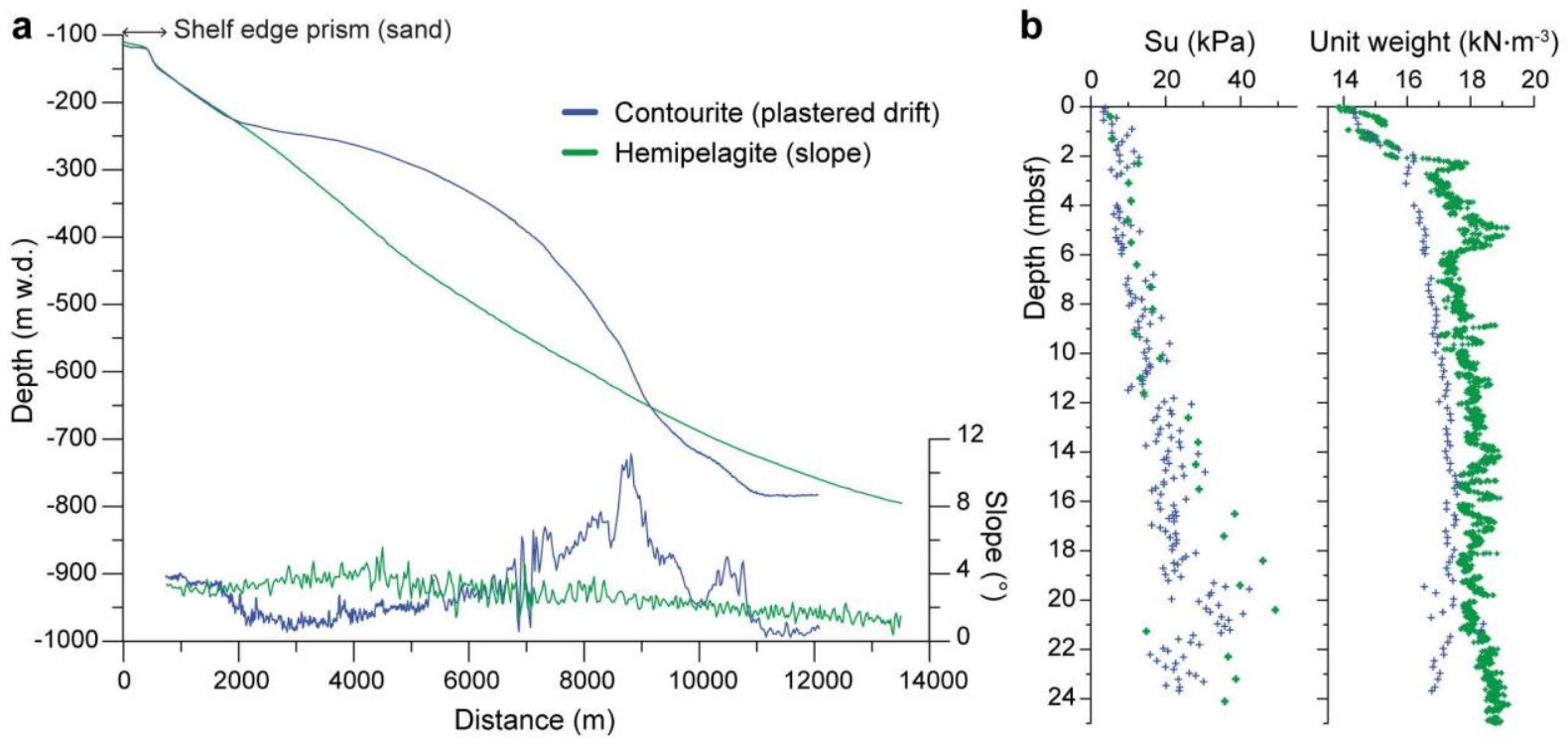

Fig. 8 a Bathymetric profiles and slope gradients of a contouritic margin (blue) and a hemipelagicturbiditic margin (green). b Undrained shear strength $(\mathrm{Su})$ and unit weight of the sediment used for the slope stability analysis: in blue a contourite (plastered drift, PSM3-CS017) and in green a hemipelagic deposit (GDEC4-2). See Fig. 1 for profile and core location 


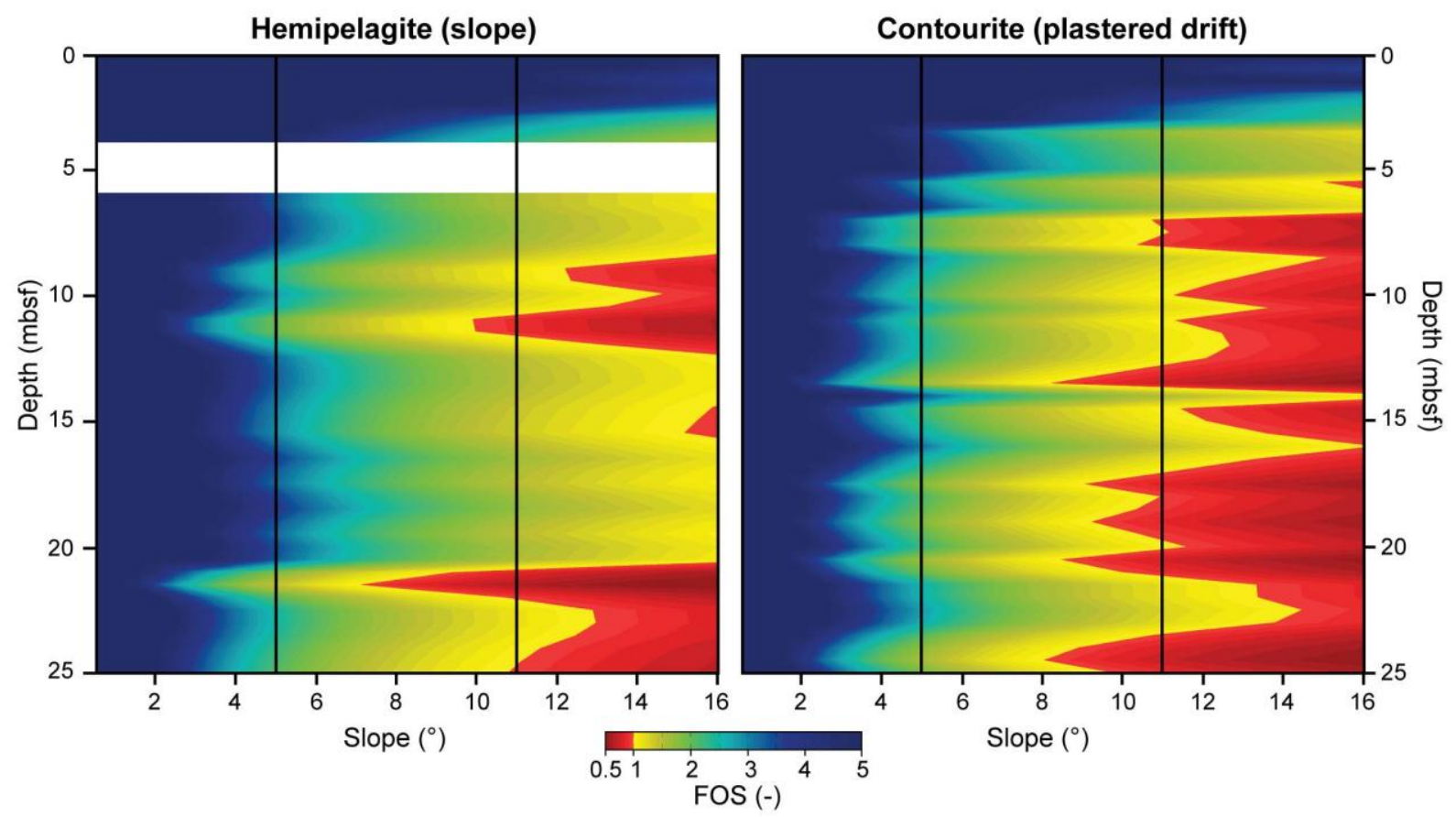

Fig. 9 Slope stability analysis showing the Factor Of Safety (FOS) as function of slope angle and depth under undrained conditions in a hemipelagic deposit and in a contourite (plastered drift). The black vertical lines show the maximum slope gradients found in the bathymetric profiles of Fig. 8a in hemipelagites $\left(5^{\circ}\right)$ and in the plastered drift $\left(11^{\circ}\right)$. FOS was not calculated in a sandy layer of GDEC4-2 and it was left blank. Note that both types of sediments present FOS $>1$ with the typical slopes of hemipelagic margins (slope $<5^{\circ}$ )

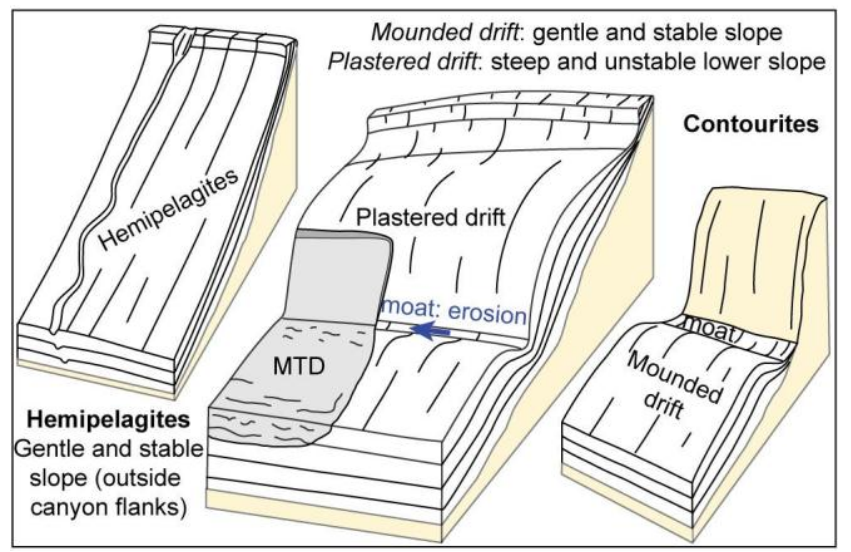

Fig. 10 Geomorphological comparison of hemipelagic and contouritic slopes. Note that slope failures are initiated in the lower part of the plastered drift. MTD: Mass Transport Deposit 


\section{Table caption}

Table 1 Physical and sedimentological properties of cores from the Pianosa Contourite Depositional System (PSM3 cores), from the basin (borehole GDEC8-2) and from the western flank of the Corsica Trough (borehole GDEC4-2)

\begin{tabular}{|c|c|c|c|c|c|c|c|c|}
\hline $\begin{array}{l}\text { Sample } \\
\text { name }\end{array}$ & Type of sediment & $\begin{array}{l}\text { Density } \\
\left(\mathrm{g} \cdot \mathrm{cm}^{-3}\right)\end{array}$ & $\begin{array}{c}\text { P-wave } \\
\text { velocity }\left(\mathrm{m} \cdot \mathrm{s}^{-1}\right)\end{array}$ & $\begin{array}{l}\text { Mean grain } \\
\text { size }(\mu \mathrm{m})\end{array}$ & $\begin{array}{l}\text { Clay volume } \\
(\%,<6.2 \mu \mathrm{m})\end{array}$ & $\begin{array}{c}\text { Silt volume } \\
(\%, 6.2-63 \mu \mathrm{m})\end{array}$ & $\begin{array}{c}\text { Sand volume } \\
(\%, 63-2000 \mu \mathrm{m})\end{array}$ & $\begin{array}{c}\text { Moisture } \\
\text { content (\%) }\end{array}$ \\
\hline PSM3 cores & Contourite & $1.4-1.85$ & $1460-1580$ & $\begin{array}{c}13-17 \\
\text { (excluding } \\
\text { sandy layers) }\end{array}$ & $\begin{array}{c}\text { Muddy } \\
\text { plastered } \\
\text { drift: } 45-64 \\
\text { Muddy } \\
\text { mounded } \\
\text { drifts: } 35-60 \\
\text { Sandy layers } \\
\text { mounded } \\
\text { drifts: } 14-24\end{array}$ & $\begin{array}{c}\text { Muddy } \\
\text { plastered drift: } \\
31-39 \\
\text { Muddy } \\
\text { mounded drifts: } \\
26-50 \\
\text { Sandy layers } \\
\text { mounded drifts: } \\
15-34\end{array}$ & $\begin{array}{l}\text { Muddy plastered } \\
\text { drift: } 6-16 \\
\text { Muddy mounded } \\
\text { drifts: } 7-19 \\
\text { Sandy layers } \\
\text { mounded drifts: } \\
45-70\end{array}$ & $\begin{array}{c}40-64 \\
\text { (max at the } \\
\text { seafloor } \\
123 \% \text { and } \\
\text { some layers } \\
\text { up to } 80-89 \% \text { ) }\end{array}$ \\
\hline GDEC8-2 & $\begin{array}{l}\text { Hemipelagite } \\
\text { (basin) }\end{array}$ & $1.4-2.0$ & $1460-1580$ & $55-130$ & $26-62$ & $28-61$ & $10-15$ & $\begin{array}{c}\text { 32-48 } \\
\text { (max at the } \\
\text { seafloor } 95 \% \text { ) }\end{array}$ \\
\hline GDEC4-2 & $\begin{array}{l}\text { Hemipelagite } \\
\text { (western slope) }\end{array}$ & $1.4-2.0$ & $1460-1580$ & $20-43$ & $27-56$ & $38-55$ & $11-14$ & $\begin{array}{c}32-48 \\
\text { (max at the } \\
\text { seafloor } 95 \% \text { ) }\end{array}$ \\
\hline
\end{tabular}

